\title{
Transcriptomic responses to grazing reveal the metabolic pathway leading to the biosynthesis of domoic acid and highlight different defense strategies in diatoms
}

\author{
Sara Harðardóttir ${ }^{{ }^{*}}\left(\mathbb{D}\right.$, Sylke Wohlrab ${ }^{2,3}$, Ditte Marie Hjort ${ }^{1}$, Bernd Krock ${ }^{2}$, Torkel Gissel Nielsen ${ }^{4}$, Uwe John $^{2,3^{*}}$
} and Nina Lundholm

\begin{abstract}
Background: A major cause of phytoplankton mortality is predation by zooplankton. Strategies to avoid grazers have probably played a major role in the evolution of phytoplankton and impacted bloom dynamics and trophic energy transport. Certain species of the genus Pseudo-nitzschia produce the neurotoxin, domoic acid (DA), as a response to the presence of copepod grazers, suggesting that DA is a defense compound. The biosynthesis of DA comprises fusion of two precursors, a C10 isoprenoid geranyl pyrophosphate and L-glutamate. Geranyl pyrophosphate (GPP) may derive from the mevalonate isoprenoid (MEV) pathway in the cytosol or from the methyl-erythritol phosphate (MEP) pathway in the plastid. L-glutamate is suggested to derive from the citric acid cycle. Fragilariopsis, a phylogenetically related but nontoxic genus of diatoms, does not appear to possess a similar defense mechanism. We acquired information on genes involved in biosynthesis, precursor pathways and regulatory functions for DA production in the toxigenic Pseudo-nitzschia seriata, as well as genes involved in responses to grazers to resolve common responses for defense strategies in diatoms.
\end{abstract}

Results: Several genes are expressed in cells of Pseudo-nitzschia when these are exposed to predator cues. No genes are expressed in Fragilariopsis when treated similarly, indicating that the two taxa have evolved different strategies to avoid predation. Genes involved in signal transduction indicate that Pseudo-nitzschia cells receive signals from copepods that transduce cascading molecular precursors leading to the formation of DA. Five out of seven genes in the MEP pathway for synthesis of GPP are upregulated, but none in the conventional MEV pathway. Five genes with known or suggested functions in later steps of DA formation are upregulated. We conclude that no gene regulation supports that L-glutamate derives from the citric acid cycle, and we suggest the proline metabolism to be a downstream precursor.

Conclusions: Pseudo-nitzschia cells, but not Fragilariopsis, receive and respond to copepod cues. The cellular route for the C10 isoprenoid product for biosynthesis of DA arises from the MEP metabolic pathway and we suggest proline metabolism to be a downstream precursor for L-glutamate. We suggest 13 genes with unknown function to be involved in diatom responses to grazers.

\footnotetext{
*Correspondence: sara.hardardottir@snm.ku.dk; uwe.john@awi.de

${ }^{1}$ Natural History Museum of Denmark, University of Copenhagen, Øster

Farimagsgade 5, 1353 Copenhagen K, Denmark

${ }^{2}$ Alfred Wegener Institute, Helmholtz Centre for Polar and Marine

Research, Am Handelshafen 12, 27570 Bremerhaven, Germany

Full list of author information is available at the end of the article
}

C The Author(s) 2019. This article is distributed under the terms of the Creative Commons Attribution 4.0 International License (http://creativecommons.org/licenses/by/4.0/), which permits unrestricted use, distribution, and reproduction in any medium, provided you give appropriate credit to the original author(s) and the source, provide a link to the Creative Commons license, and indicate if changes were made. The Creative Commons Public Domain Dedication waiver (http://creativecommons.org/ publicdomain/zero/1.0/) applies to the data made available in this article, unless otherwise stated. 
Keywords: Pseudo-nitzschia, Fragilariopsis, Grazer induced defense, Domoic acid, Gene expression, Methyl-erythritol phosphate metabolic pathway, Geranyl pyrophosphate, L-Glutamate, Proline

\section{Background}

Phytoplankton survival depends, among other factors, on the capability to defend the cells against grazing zooplankton. Predation is the main source of phytoplankton mortality [1] and diatoms have evolved a variety of strategies to reduce predation. Thick silicate frustules and spiny armors, formation of toxins, adaptable cell sizes and formation of long chains are examples of defense traits in diatoms [2]. Defense mechanisms induced by the presence of predators require cells to sense and recognize the predator from a distance. Diatoms exhibit complex signaling mechanisms that allow perception of environmental cues such as the presence of gametes of opposite sex and the presence of bacteria [3, 4]. Diatoms of the genera Pseudo-nitzschia and Skeletonema respond to predator cues from copepods: at least two Pseudo-nitzschia species by inducing toxin production, and Skeletonema marinoi by shortening the chain length [5-7]. The induced defense responses are both diatom specific and predator specific [5-7]. Thus two phylogenetically related diatoms, Fragilariopsis cylindrus and Niztschia frigida, do not induce formation of domoic acid (DA). Pseudo-nitzschia seriata elicits induced DA production in response to predator cues from herbivorous copepods, but when exposed to a copepod carnivore, a response is not elicited [8]. Predator cues as referred to in this paper are info-chemical signals that mediate interactions between two individuals and result in an adaptive response in the receiver, here specifically copepodamides excreted by copepods [9]. Presently, 21 copepodamide compounds have been identified and their composition is copepod species specific [10]. Pseudo-nitzschia seriata increases DA production as a response to the naturally occurring mixture of copepods and to at least three isolated copepodamides in ecosystem-relevant doses [10, 11]. Cellular signal transduction depends on the perception of external cues, but how the diatoms or other phytoplankton species perceive the predator cues is still poorly understood. Perception by signal transduction via $G$ protein-coupled receptors is proposed for the dinoflagellate Alexandrium catenella exposed to a heterotrophic dinoflagellate grazer [12]. When exposed to different grazers (copepods), the induced defense response and the discrimination between copepod species were suggested to be regulated by protein kinases and calcium signaling [13]. To our knowledge, only one other study has investigated the molecular mechanism behind grazer-induced defense mechanisms in a diatom. Gene regulation and metabolomic response in Skeletonema marinoi as a response to grazers showed that transcripts linked to G protein-coupled receptors and to nitric oxide synthesis were differentially expressed, and that Skeletonema reacts the same way in the presence of two different copepod species [14].

Several species of the diatom genera Pseudo-nitzschia and Nitzschia pose a threat to organisms in the marine environment due to their ability to produce DA, a marine biotoxin known to cause severe harm up the food web, and amnesic shellfish poisoning in humans. To date 52 Pseudo-nitzschia species are described and exactly half of these (26) plus two Nitzschia species have been reported to produce DA [15]. Pseudo-nitzschia was demonstrated to be a source of DA already in 1988, but the ecological role of toxin production is still not fully understood. Pseudo-nitzschia cells react to several abiotic and biotic environmental factors such as changes in light, temperature, salinity, $\mathrm{pH}, \mathrm{pCO}_{2}$ and nutrient levels, as well as to the presence of bacteria and grazers by changing the production of toxins $[16,17]$.

As a result of a major research effort which began during the early 1990s, the biosynthetic pathway of DA is gradually being uncovered. Using ${ }^{13} \mathrm{C}$ - and ${ }^{14} \mathrm{C}$-labelled precursors to detect the major metabolic pathways for DA synthesis, it was suggested that DA originates from condensation of a $\mathrm{C} 10$ isoprenoid with a tricarboxylic acid (a product of the citric acid cycle) $[18,19]$. The precursor of the $\mathrm{C} 10$ isoprenoid was suggested to be geranyl pyrophosphate (GPP) and originate from acetyl CoA through the mevalonate (MEV) pathway [20] and the tricarboxylic acid proposedly derives from L-glutamate [18]. GPP is synthesized through the isopentenyl pyrophosphate pathway and originate either through (1) the proposed MEV pathway located in the cytosol and/or (2) an alternative route in the plastid, the methyl-erythritol phosphate metabolic (MEP) pathway [21] (Additional file 1: Figure S1). Both pathways are present in diatoms but the MEP pathway is not complete in all diatoms [21, 22]. The early findings have been confirmed and it was demonstrated that the amino function in DA is generated by nucleophilic displacement of GPP by an unknown intermediate [23]. Recently, six compounds with potential functions in the condensation of GPP and L-glutamate were identified and their structure described [24]. The same study also confirmed $\mathrm{N}$-geranyl-L-glutamic acid as a potential intermediate. Four candidate genes, DabA-D, that can code for the condensation of GPP and 
L-glutamate towards DA were recently identified [25]. These four genes were upregulated under phosphate limitation or elevated $\mathrm{pCO}_{2}$, both conditions known to induce DA production [26]. DabA catalyzes the $\mathrm{N}$-geranylation of L-glutamate to form $N$-geranyl-L-glutamic acid, while DabC and D catalyze dainic and isodomoic acids. The final isomerization reaction to complete the condensation to DA remains unknown. Another tricarboxylic acid, proline, a structural analog to DA, is suggested to be implicated in DA biosynthesis. Based on isotopic labeling pattern of DA, a coupling of DA production to the proline metabolism was suggested [18]. Proline could be an upstream precursor of DA, and a correlation between Pseudo-nitzschia cells with high accumulation of DA and low proline content has been found [27].

The principal aim of this study is (1) to acquire information on genes involved in the metabolic processes of DA synthesis in a species of Pseudo-nitzschia. For revealing whether the MEP or the MEV pathway is a part of the metabolic pathway, and whether we can confirm previous suggestions on genes involved in DA synthesis. (2) To acquire information on the molecular mechanism of perception of predator cues by studying transcriptional processes in the two diatoms Pseudo-nitzschia and Fragilariopsis. The target species tested are $P$. seriata, known to induce DA when exposed to predator cues, and a species of Fragilariopsis not known to induce this defense mechanism.

\section{Results}

\section{Domoic acid content and growth rates}

The cellular toxin content in Pseudo-nitzschia increased by sevenfold ( $t$-test $P=0.032$ ) as a response to predator cues exposure, while no increased toxin production was found in the controls ( $\mathrm{t}$-test $\mathrm{P}=0.19)$. Fragilariopsis did not produce DA neither in response to grazer cues nor in the control. Both species grew exponentially and Fragilariopsis had a higher division rate than Pseudo-nitzschia (t-test $\mathrm{P}<0.05) 0.64 \pm 0.01 \mathrm{day}^{-1}$ and $0.12 \pm 0.06$ day $^{-1}$, respectively. (See details on DA levels and division rates in Table 1).

\section{Overview of gene expression profiles in Pseudo-nitzschia and Fragilariopsis when exposed to predator cues}

Of the two diatoms, only Pseudo-nitzschia showed differential gene expression when exposed to predator cues (Fig. 1). In total 1128 genes were differentially expressed, of which 814 genes were upregulated and 314 genes downregulated compared to the control (Additional file 2: Tables S1 and S2). Based on the KEGG and KOG databases, 285 of the regulated genes (25\% of the total) have a functional annotation. The remaining $75 \%$ of the regulated genes have a BLAST hit but could not be assigned to any specific function. These contigs are comparable to sequences in the data bases but their function is unknown. The assembly information is given in Table 2.

Several genes involved in major metabolic pathways such as amino acid, carbohydrate and lipid metabolism are differentially expressed, with the majority $(>70 \%)$ of genes being upregulated compared to the control (Fig. 2). Differentially expressed genes assigned to the category of cellular information processing mainly showed a higher expression compared to the control. Genes were differentially regulated, both up and down, in the category of genetic information processing with functions in folding, sorting and degradation of RNA as well as replication and repair. In the category of environmental information processing, the 22 differentially expressed genes were equally either down- or upregulated (Fig. 2). Most importantly five upregulated genes have a function in the isopentenyl pyrophosphate pathway, assigned to the category of terpenoid and polyketide synthesis (highlighted green in Figs. 2 and 3), these are candidate genes for the C10 isoprenoid in the biosynthesis of DA. The majority of

Table 1 Cell concentrations at the start of the experimental treatments, cellular growth rates and cellular domoic acid (DA) contents

\begin{tabular}{|c|c|c|c|}
\hline Diatom treatment & \# Cells start/end (cells $\mathrm{mL}^{-1}$ ) & Division rate $\left(\right.$ day $\left.^{-1}\right)$ & $\begin{array}{l}\text { Cellular DA start/ } \\
\left.\text { end (pg DA cell }{ }^{-1}\right)\end{array}$ \\
\hline \multicolumn{4}{|l|}{ Pseudo-nitzschia } \\
\hline Predator cues & $3947 \pm 189 / 4952 \pm 627$ & $0.10 \pm 0.06$ & $0.1 \pm 0.01 / 0.7 \pm 0.2$ \\
\hline Control & $4245 \pm 297 / 5924 \pm 750$ & $0.15 \pm 0.05$ & $0.1 \pm 0.01 / 0.1 \pm 0.02$ \\
\hline \multicolumn{4}{|l|}{ Fragilariopsis } \\
\hline Predator cues & $2797 \pm 38 / 6768 \pm 156$ & $0.63 \pm 0.01$ & nd \\
\hline Control & $2771 \pm 10 / 6644 \pm 192$ & $0.64 \pm 0.01$ & nd \\
\hline
\end{tabular}

Number of replicates $=3$. Results are given as mean and standard deviation, $\mathrm{nd}=$ no detection 


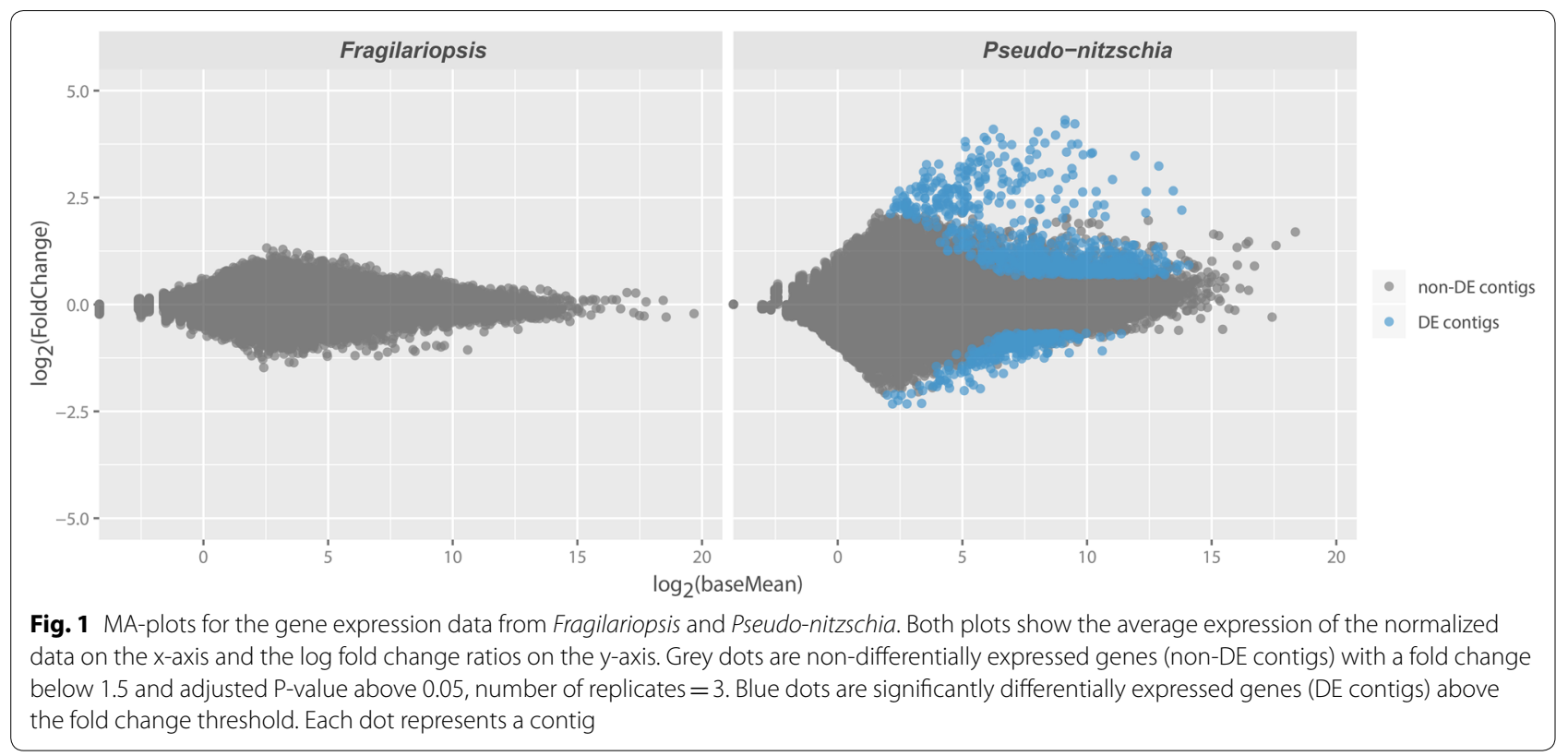

Table 2 Summary of RNAseq assemblies for Pseudonitzschia and Fragilariopsis number of replicates $=3$

\begin{tabular}{lll}
\hline & Pseudo-nitzschia & Fragilariopsis \\
\hline Number of reads & 272.616 .642 & 263.814 .668 \\
N 50 & 1759 & 1375 \\
Number of contigs & 66.423 & 71.590 \\
Average contig length BP & 811 & 788 \\
\hline
\end{tabular}

contigs could not be assigned to a function. All of the contigs with highest upregulation belong to this category.

\section{Signal transduction}

We searched the transcripts for genes involved in cellular signal transduction, as the perception of external cues must transduce cascading molecular responses. A vesicular neurotransmitter transporter with a known function as extra cellular membrane interaction transporter (PSN0026807) is downregulated. Translation initiation factor 4E (PSN0006232) and serum/glucocorticoid-regulated kinase 2 (PSN0000383) are upregulated as well as GTP-binding protein (PSN0015960) and a RING-type E3 ubiquitin transferase (PSN00338470). Downstream regulator for G-binding proteins, mitogen-activated protein kinase (PSN0000026) and a mitogen-activated protein kinase homolog (PSN001617) are downregulated. The results indicate that Pseudo-nitzschia transduce signals from the copepods via $G$ protein pathways. Nitric oxide signaling may be involved in the response to grazers and a nitric oxide synthase-interacting protein (PSN0002048) is upregulated. Genes in the category of signal transduction differentially expressed in Pseudo-nitzschia as response grazers are listed in Table 3.

\section{Candidate genes for stress}

There is strong indication that Pseudo-nitzschia cells are under stress when exposed to grazers. Various genes known to be a response to stressors are upregulated. Heat shock proteins and transcription factors are among the highly upregulated genes, like the HSP90 and one of its homologs HSP90-7, HSP40, heat shock factor protein 2 , heat stress transcription factor A-2, and cytochrome P450 genes. Genes indicating cellular stress in Pseudonitzschia as response to the presence of grazers are listed in Table 4.

\section{Common grazing responses in diatoms}

In Fragilariopsis, not a single gene is differentially expressed as a response to grazers (Fig. 1). When comparing the regulated nucleotide sequences in Pseudonitzschia with a similar study conducted on Skeletonema [14] we found congruence in upregulated genes. We found 13 genes, (out of only 34 and 55 matches, depending on time point in Skeletonema) that match upregulated genes in Skeletonema (Additional file 1: Figure S2; Additional file 3: Tables S5 and S6). Unfortunately, all these 13 genes lack annotations, which makes it difficult to reconstruct mechanisms for the response (Table 5). However, 10 of these 13 genes seem to be functionally related i.e. they show high similarities at the nucleotide level 


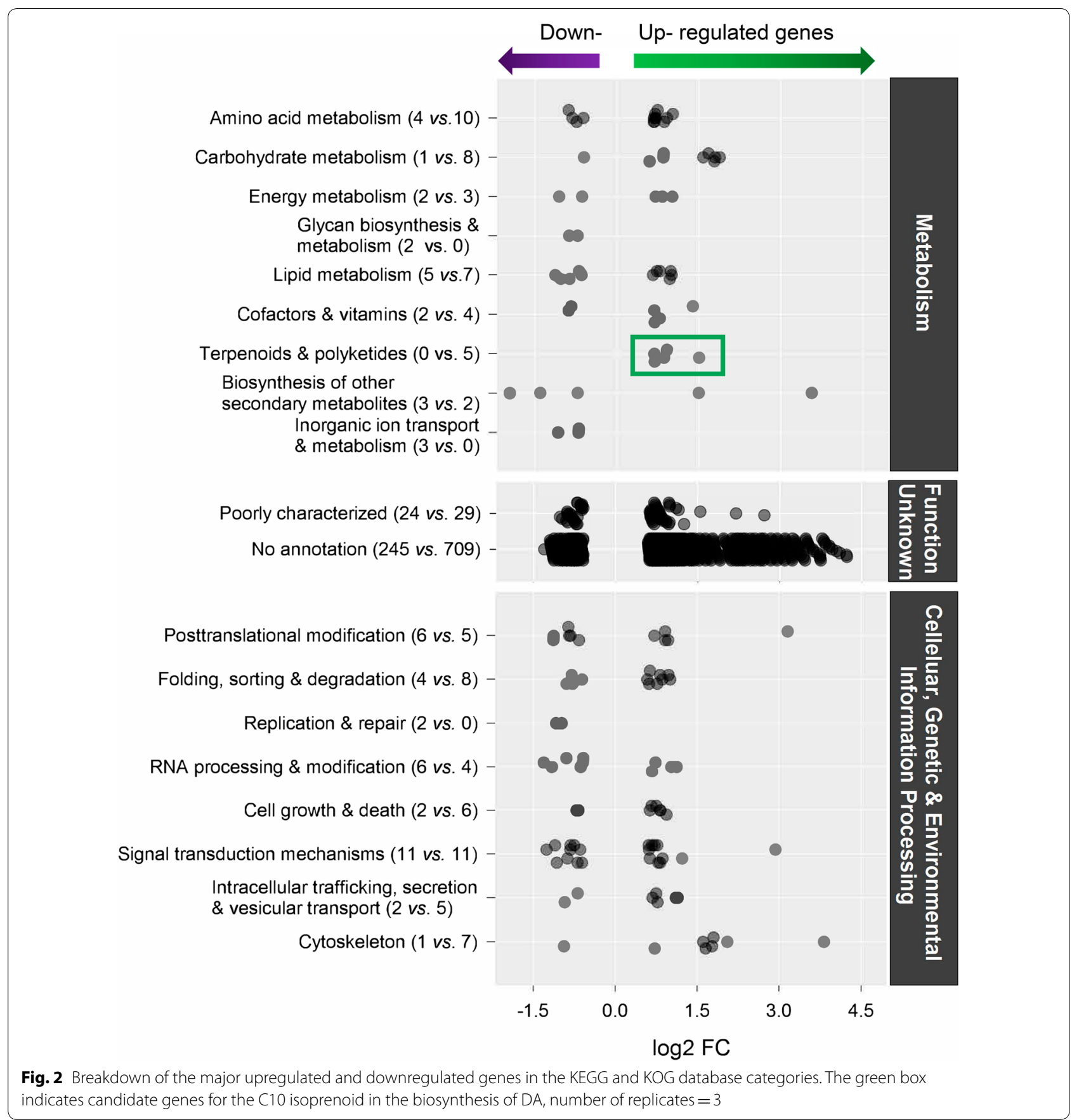

(Additional file 1: Figure S3; Additional file 3: Table S9). The oxide synthase-interacting protein (PSN0002048) is upregulated, but this not a homolog to c9307_gl_il in [14] or MMMETSP104-20121108 1594 in [22].

\section{Candidate genes for domoic acid biosynthesis}

Based on evidence and indications in earlier studies of DA production in Pseudo-nitzschia, we searched specifically for genes involved in the regulation of the isopentenyl pyrophosphate pathway, such as acetyl-CoA, isopentenyl pyrophosphate (via both the MEV and MEP pathways), GPP biosynthesis, L-glutamate biosynthesis including proline degradation into L-glutamate, and the citric acid cycle. All genes involved in both pathways to isopentenyl pyrophosphate were confirmed to be present in the transcriptome of Pseudo-nitzschia and Fragilariopsis. Five out of seven genes coding for enzymes involved in the MEP pathway were upregulated under 


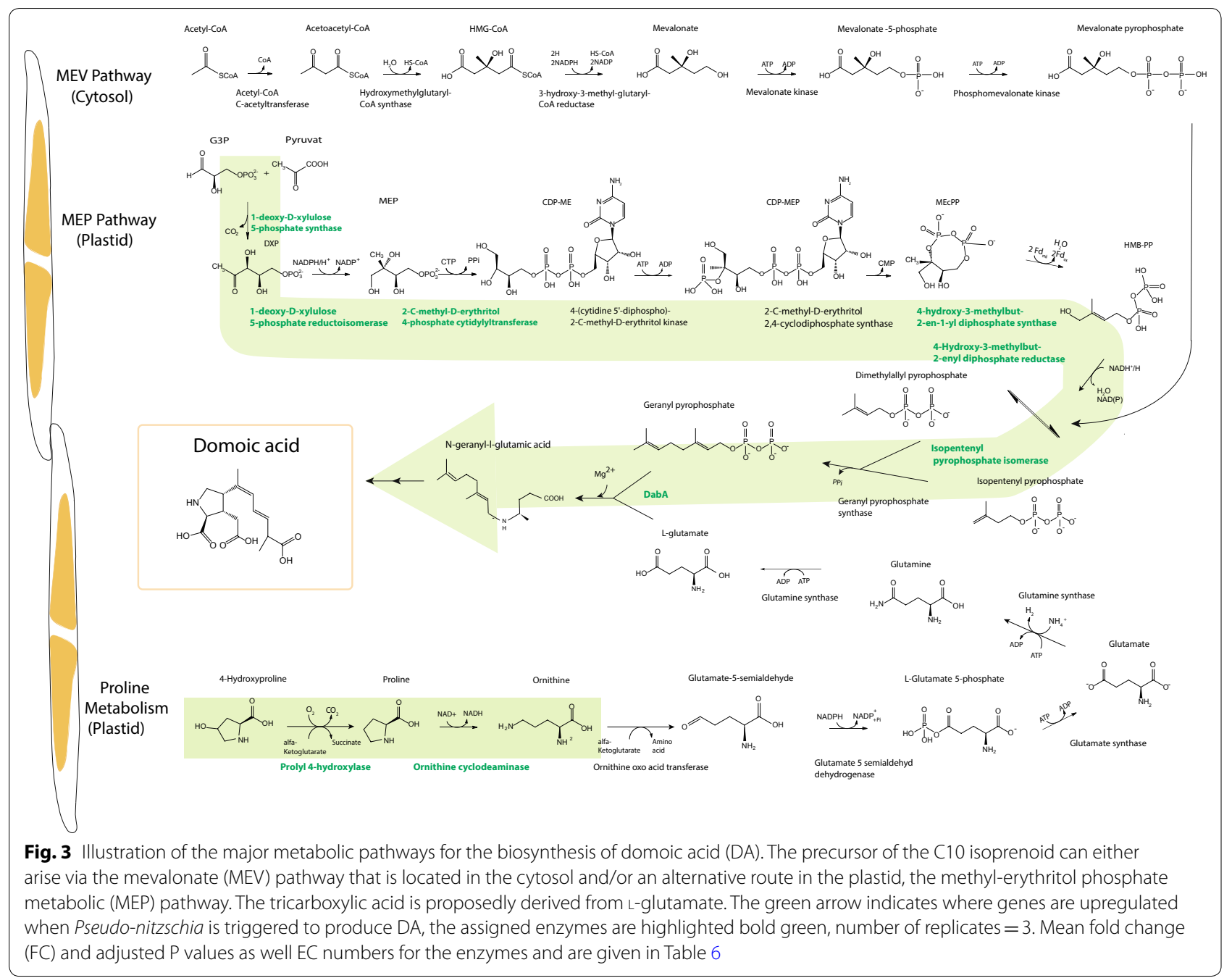

grazer-induced DA induction. The gene encoding for isopentenyl pyrophosphate isomerase responsible for the condensation into GPP was also upregulated, as was the DabA gene involved in the condensation of $\mathrm{N}$-geranylL-glutamic acid (Table 6, Fig. 3). None of the six genes in the proposed MEV pathway were significantly differentially expressed (Fig. 3). The non-significant regulation of the genes in the MEV pathway is randomly up or downregulated. Genes directly involved in the synthesis of L-glutamate: glutamate dehydrogenase [EC: 6.3.1.2] and glutamate synthase [EC: 4.7.1; EC:1.4.13; EC:1.4.13] were not differentially expressed compared to the control. No gene regulation was detected in genes known to encode for enzymes in the citric acid cycle. But prolyl 4-hydroxylase and ornithine cyclodeaminase [EC: 1.14.11.2 and 4.3.1.12], directly involved in the formation of proline, were upregulated (Fig. 3, Table 6), indicating proline to be the downstream precursor for L-glutamate.

\section{Comparison with other studies on the biosynthetic} pathway in Pseudo-nitzschia by gene expression analysis Gene expression in Pseudo-nitzschia multiseries at low and high DA production induced by silicate limitation has been investigated [28]. When comparing exponential vs. stationary phase, the study suggests 12 genes to be involved in DA production. Ten of these are present in Pseudo-nitzschia seriata but were not differentially expressed at induced DA conditions. By investigating three Pseudo-nitzschia species, one of which is toxigenic, Pseudo-nitzschia multistriata, one gene involved in nitrite oxide synthesis was confirmed to be present only in the DA-producing strain [22]. Neither this gene sequence nor any other hit for a nitric oxide synthesis enzyme was present in $P$. seriata in our study. Gene expression in $P$. multistriata was investigated under two DA-inducing conditions, phosphate limitation and elevated $\mathrm{pCO}_{2}$ [25]. We looked for regulation of genes involved in either of the isoprenoid pathways within the 
Table 3 Differentially expressed gene involved in signal transduction

\begin{tabular}{|c|c|c|c|c|c|}
\hline \multicolumn{6}{|c|}{ Signal transduction } \\
\hline $\begin{array}{l}\text { Accession } \\
\text { number }\end{array}$ & Mean FC & $\begin{array}{l}\text { Adjusted P } \\
\text { values }\end{array}$ & Gene name & Description & $\begin{array}{l}\text { Enzyme } \\
\text { EC: }\end{array}$ \\
\hline PSN0008622 & 7.64 & $<0.001$ & NA & Leucine rich repeat & NA \\
\hline PSN0015333 & 2.34 & 0.006 & NA & Tyrosine kinase specific for activated GTP bound p21 cdc $42 \mathrm{Hs}$ & NA \\
\hline PSN0007679 & 1.82 & 0.01 & NA & Natriuretic peptide receptor guanylate cyclase & NA \\
\hline PSN0000026 & 1.77 & 0.025 & NA & MEKK and related serine threonine protein kinases & NA \\
\hline PSN0022790 & 1.73 & 0.047 & NA & Predicted GTPase activating protein & NA \\
\hline PSN0012156 & 1.71 & $<0.001$ & FLS2 & LRR receptor-like serine threonine-protein kinase & 2.7.11.1 \\
\hline PSN0007370 & 1.65 & 0.027 & NA & Tyrosine kinase specific for activated GTP bound p21 cdc $42 \mathrm{Hs}$ & NA \\
\hline PSN0001687 & 1.62 & 0.002 & NA & Tyrosine kinase specific for activated GTP bound p21 cdc $42 \mathrm{Hs}$ & 4.3.1.12 \\
\hline PSN0015960 & 1.62 & $<0.001$ & RRAGA B & GTP binding protein & \\
\hline PSN0008559 & 1.58 & 0.017 & CALM & Calmodulin and related proteins EF hand superfamily & NA \\
\hline PSN0008776 & 1.53 & 0.013 & NA & Tyrosine kinase specific for activated GTP bound p21cdc42Hs & NA \\
\hline PSN0004431 & 1.53 & 0.024 & NA & $\mathrm{Ca} 2+$ calmodulin dependent protein kinase EF hand protein superfamily & NA \\
\hline PSN0026544 & -1.56 & 0.031 & NA & Tyrosine kinase specific for activated GTP bound p21 cdc $42 \mathrm{Hs}$ & NA \\
\hline PSN0014002 & -1.6 & 0.026 & NA & Tyrosine kinase specific for activated GTP bound p21cdc42Hs & NA \\
\hline PSN0009159 & -1.61 & 0.0183 & NA & Uncharacterized conserved protein & NA \\
\hline PSN0006134 & -1.68 & $<0.001$ & NA & LRR receptor-like serine threonine-protein kinase & NA \\
\hline PSN0008421 & -1.76 & 0.005 & PDCD4 & Neoplastic transformation suppressor Pdcd4 MA 3 contains MA3 domain & NA \\
\hline PSN0012753 & -1.77 & $<0.001$ & NA & Leucine-rich repeat receptor-like protein kinase & NA \\
\hline PSN0018357 & -1.83 & 0.007 & NA & CDK5 activator binding protein & NA \\
\hline PSN0004142 & -1.9 & $<0.001$ & NA & Endocytosis signaling protein EHD1 & NA \\
\hline PSN0016217 & -2.15 & 0.039 & NA & Serine threonine specific protein phosphatase PP1 catalytic subunit & NA \\
\hline PSN0000124 & -2.37 & 0.008 & NA & Endocytosis signaling protein EHD1 & NA \\
\hline
\end{tabular}

Mean fold change $(\mathrm{FC})$ and adjusted $P$ values are based on three replicates

Table 4 Differently expressed genes indicating cellular stress in Pseudo-nitzschia in presence of predator cues from Calanus

\begin{tabular}{lcclll}
\hline Cellular stress & & & & & \\
\hline Accession number & Mean FC & Adjusted P value & Gene name & Description & $\begin{array}{l}\text { Enzyme } \\
\text { EC: }\end{array}$ \\
\hline PSN0046491 & 3.76 & 0.004 & HSF2 & Heat shock factor protein 2 & NA \\
PSN0008255 & 2.6 & $<0.001$ & RALDH1/ALDH-E1 & Retinal dehydrogenase/aldehyde dehydrogenase family 1 & 1.2 .36 \\
PSN0002391 & 1.7 & 0.001 & DNAJB2 & Homolog subfamily B member 2/Heat shock 40 kDa protein 3 & NA \\
PSN0017080 & 1.63 & 0.042 & HSF 1/HSTF 3A & Heat shock factor protein 1 & NA \\
PSN0009322 & 1.56 & 0.016 & OSHsf-18 & Heat stress transcription factor-A-2b & NA \\
PSN0001244 & 1.5 & 0.044 & HSP90B & Heat shock protein 90 kDa beta & NA \\
PSN0002436 & -1.6 & 0.037 & CYPIVDS8 & Cytochrome P450 4d8 & NA \\
PSN0019585 & -2.03 & 0.003 & NA & Glutathione S-transferase & NA \\
\hline
\end{tabular}

Mean fold change (FC) and adjusted $P$ values are based on three replicates

P. multistriata data set available on JGI, but did not find direct evidence for either pathway. One gene upregulated under all three conditions (grazer exposure, phosphate limitation and elevated $\mathrm{pCO}_{2}$ ) is PSN000450, which encodes for an enzyme in the MEP pathway (Table 6, Fig. 3). All four (DabA-D) genes from the [25] study are upregulated in P. seriata (Table 6, Fig. 3) and are not present in Fragilariopsis.

Among the 1028 regulated nuclear contigs in $P$. seriata, 441 match the 788 protein sequences in $P$. multistriata. Out of those, 23 are regulated in $P$. seriata exposed to grazers, and in $P$. multistriata under 
Table 5 Differently expressed genes we suggest to be common diatom responses to grazers

\begin{tabular}{|c|c|c|c|c|c|}
\hline \multicolumn{6}{|l|}{ Grazing } \\
\hline Accession number & Mean FC & Adjusted P value & Gene name & Description & $\begin{array}{l}\text { Enzyme } \\
\text { EC: }\end{array}$ \\
\hline PSN0003667 & 10.12 & $<0.001$ & NA & NA & NA \\
\hline PSN0003517 & 8.76 & $<0.001$ & NA & Cell wall-associated hydrolase & NA \\
\hline PSN0000079 & 6.23 & 0.007 & NA & Cell wall-associated hydrolase & NA \\
\hline PSN0000487 & 6.19 & 0.008 & NA & NA & NA \\
\hline PSN0001476 & 5.02 & 0.027 & NA & NA & NA \\
\hline PSN0008314 & 4.87 & 0.026 & NA & NA & NA \\
\hline PSN0001176 & 4.72 & 0.024 & NA & NA & NA \\
\hline PSN0000367 & 4.66 & 0.035 & NA & NA & NA \\
\hline PSN0000066 & 4.61 & 0.029 & NA & Cell wall-associated hydrolase & NA \\
\hline PSN0000080 & 4.5 & 0.021 & NA & Cell wall-associated hydrolase & NA \\
\hline PSN0001342 & 4.46 & 0.045 & NA & NA & NA \\
\hline PSN0000500 & 4.27 & 0.015 & NA & NA & NA \\
\hline PSN0005577 & 2.43 & 0.019 & NA & NA & NA \\
\hline
\end{tabular}

Mean fold change (FC) and adjusted $P$ values are based on three replicates

Table 6 Genes regulated in the domoic acid (DA) induced grazer treatments that are involved or suggested to be involved in the biosynthesis of DA

\begin{tabular}{|c|c|c|c|c|c|}
\hline \multicolumn{6}{|l|}{ Domoic acid } \\
\hline Accession number & Mean FC & Adjusted P value & Gene name & Description & $\begin{array}{l}\text { Enzyme } \\
\text { EC: }\end{array}$ \\
\hline \multicolumn{6}{|c|}{ In the methylerythritol phosphate metabolic pathway (MEP) to geranyl pyrophosphate (GPP) } \\
\hline PSN0016235 & 1.88 & $<0.001$ & Dxr & 1-Deoxy-D-xylulose 5-phosphate reductoisomerase & 1.1.1.267 \\
\hline PSN0004050 & 1.82 & $<0.001$ & ispH & 4-Hydroxy-3-methylbut-2-enyl diphosphate reductase & 1.17.1.2 \\
\hline PSN0005356 & 1.61 & 0.043 & ispG & 4-Hydroxy-3-methylbut-2-en-1-yl diphosphate synthase & 1.17.7.1 \\
\hline PSN0002600 & 1.60 & $<0.001$ & ispD & $\begin{array}{l}\text { 2-C-Methyl-D-erythritol 4-phosphate cytidylyltransferase, } \\
\text { chloroplastic }\end{array}$ & 2.7.7.60 \\
\hline PSN0023754 & 1.60 & 0.013 & ispe & 4-Diphosphocytidyl-2-C-methyl-D-erythritol kinase & 2.7.1.148 \\
\hline \multicolumn{6}{|c|}{ In the synthesis from MEP to GPP and L-glutamate towards domoic acid } \\
\hline PSN0015669 & 12.23 & $<0.001$ & DabB & Hypothetical protein & NA \\
\hline PSN0029114 + PSN002498 & 11.23 & $<0.001$ & DabC & Dioxygenase & NA \\
\hline PSN0007588 & 9.41 & $<0.001$ & DabA & $\mathrm{N}$-prenyltransferase & NA \\
\hline PSN0005772 & 2.83 & $<0.001$ & idi1-2 & Isopentenyl-diphosphate Delta-isomerase & 5.3.3.2 \\
\hline PSN0020364 & 2.83 & $<0.001$ & DabD & Cytochrome P450 & NA \\
\hline \multicolumn{6}{|l|}{ Proline metabolism } \\
\hline PSN0000830 & 1.67 & $<0.001$ & P4HA & Prolyl 4-hydroxylase & 1.14.11.2 \\
\hline PSN0001687 & 1.62 & 0.002 & NA & Ornithine cyclodeaminase & 4.3.1.12 \\
\hline
\end{tabular}

Mean fold change (FC) and adjusted $P$ values are based on three replicates

phosphate limitation, while nine are also differentially expressed under $\mathrm{pCO}_{2}$ elevation. Thus, nine genes are differentially regulated in all three DA-inducing conditions, eight of which are upregulated and one downregulated (Additional file 1: Figure S2; Additional file 3: Tables S3 and S4).

\section{Discussion}

Diatom response to grazers

We report here $>1000$ genes differentially regulated in Pseudo-nitzschia as a response to copepod grazers while no differential gene expression was detected in Fragilariopsis under the same conditions. The two phylogenetically closely related phytoplankton species have 
therefore evolved different response strategies to threats from grazers. The lack of response in gene expression levels in Fragilariopsis indicates that in this taxon, protection against grazing might have evolved as a constitutive resistance mechanism, a trait that is always present. Hence, the results indicate that Fragilariopsis has not developed a sensory system to detect the predator cues from C. finmarchicus in the way shown here for Pseudonitzschia and for Skeletonema [14]. Fragilariopsis species are known to be fast growing and able to adapt to various types of habitat, and they successfully prevail in polar regions, both in the pelagic and in sea ice, as well as being globally distributed $[29,30]$. A thick silica frustule as in Fragilariopsis, opposed to a thinner frustule in Pseudo-nitzschia, can provide mechanical protection-an armor that the copepod either cannot break or, if consumed, may pass undamaged through the gut [31]. The lack of response at the gene expression level does not indicate grazer defense to be an inducible trait, but does not exclude that other Fragilariopsis species may modify frustule thickness on demand. Inducible defenses in diatoms triggered by presence of copepods are still scarcely studied. To date this trait has been documented only in Skeletonema and Pseudo-nitzschia. We compared our results with the available data demonstrating gene expression in Skeletonema as a response to the same grazer species, C. finmarchicus, at two time points [14, 31]. There are only 34 (time point 1 ) and 55 (time point 2) matches with the contigs from our Pseudo-nitzschia datasets, thus highlighting the genetic differences in the defense traits of the two diatoms (chain length versus toxin production). However, 13 of the genes are upregulated in Pseudo-nitzschia and Skeletonema at both time points. This strongly suggests those genes to be candidates for common grazer responses in diatoms.

The response of Pseudo-nitzschia to the predator cues, i.e. the induced DA production, supports previous findings $[6-8,10,32]$. The induction of toxins as a response to predator cues implies that DA is an induced defense mechanism. However, the defense role is still speculative as DA-containing cells are ingested by their predators independent of their toxicity. Phycotoxins may, however, be effective after ingestion. Thus, mortality has been detected in copepods after feeding on toxic Pseudonitzschia [8], and reduced escape response has been seen in copepods having fed on toxic Pseudo-nitzschia [33]. No cost of DA production is detected in this study in terms of reduction in the growth rate of Pseudo-nitzschia and the same has been seen in $[6,7,32]$. Reduction of growth rate correlated, however, with high DA production in [8]. One of the prerequisites for inducible defenses is that they save the organism energy, but reports of costs in relation to induced defense are few and this aspect needs further attention. High costs of plasticity may over time be eradicated by evolution [34, 35] and low costs (e.g. minor reduction in growth rate) can go undetected in laboratory experiments where factors such as nutrients and energy (light) are not limited [36]. Small differences may not be statistically significant but may have a strong ecological impact when scaled up to natural populations [37]. Consequently, growth as a physiological and metabolic prime parameter to estimate cost and the physiological status of the cells, might not be a sufficient way to detect the metabolic investment of unicellular organisms. Regulation of genes in the category cell growth and death were upregulated, indicating that the Pseudo-nitzschia cells are forced to relocate energy, possibly because of the allocation costs of the DA production. Cellular regulative processes and changes in metabolic pathways mirror metabolic costs in terms of energy equivalents such as consumption of ATP and NADPH. These are for example needed for the synthesis of new enzymes and metabolites. Various genes of the KEGG and KOG categories might be involved in costs of production of amino acids and carbohydrate metabolism that are essential for all protein biosynthesis, such as the provision of glucose for cellular respiration.

\section{The role of MEP in the biosynthesis of domoic acid}

Given that DA is synthesized by GPP and L-glutamate, the results of the present study reveal that the MEP pathway is a very likely precursor pathway for synthesis from GPP and further to DA. The majority of the genes in this pathway are upregulated in Pseudo-nitzschia when cells are triggered to produce DA compared to the control. The presence of both the MEP and the MEV pathways has been identified in various toxigenic and non-toxic Pseudo-nitzschia species, and in one Fragilariopsis species [22]. All genes involved in both pathways were confirmed to be present in the cDNA library of $P$. seriata and Fragilariopsis. However, we did not detect any differential gene expression of genes coding for enzymes in the MEV pathway as a response to predator cues. The MEP pathway was relatively recently fully described [38, 39] and has the same central role as the MEV pathway, to form isoprenoids. Isoprenoids are a class of organic compounds essential for all plants, for forming sterols, brassinosteroids, cytokinins, phytols, plant hormones and carotenoids [21]. The two pathways are located in different compartments of the cell, the MEV pathway in the cytosol and the MEP pathway in the plastid. Our results thus suggest that the formation of DA occurs in the plastid.

We did not detect any regulation of genes involved in the processes of the citric cycle for the proposed precursor of $\mathrm{L}$-glutamate. The only regulation detected that can 
give hints to the downstream precursors are two genes in the proline metabolism. This supports the hypothesis that proline is coupled with the synthesis of DA. In theory, proline can be metabolized to L-glutamate as illustrated on Fig. 3. However, proline is a stress-related amino acid in many plants and algae [40-42] and may be regulated for other purposes than DA synthesis.

\section{Conclusions}

We propose that the $\mathrm{C} 10$ isoprenoid product for biosynthesis of DA arises from the plastid MEP pathway rather than the cytosolic MEV pathway, as five out of seven genes involved in the MEP pathway are upregulated in Pseudo-nitzschia cells triggered to produce DA. We did not detect any gene-regulation that can be traced to the proposed L-glutamate from the citric acid cycle as precursor for DA, but suggest that the L-glutamate precursor could derive from the proline metabolism. Further, we demonstrate that the two phylogenetically closely related species have evolutionary distinctly different strategies for coping with grazer threats and only Pseudo-nitzschia responds with an induced defense when exposed to predator cues. Finally, we suggest 13 genes with unknown function to be involved in the responses of diatoms to grazers.

\section{Methods}

\section{Organisms and experimental set up}

The diatom strains were established from samples collected in Disko Bay, Greenland and permission for sampling was issued by The Government of Greenland, Naalakkersuisut. Pseudo-nitzschia seriata (strain Disko 8) was isolated, June 2013; Fragilariopsis sp. (strain A4-14) was isolated, May 2014. Biovolume of Disko 8 cells is $1695 \mu \mathrm{m}^{3}$ and of A4-14 is $\sim 830 \mu \mathrm{m}^{3}$. The strain of $P$. seriata Disko 8 has previously been shown to produce DA in the exponential growth phase as a response to predator cues from Calanus finmarchicus as well as to isolated compounds of predator cues, a group of polar lipids named copepodamides [9]. Both strains were cultured at the University of Copenhagen in L-medium [43] at $4{ }^{\circ} \mathrm{C}$ and a light:dark cycle of $16: 8 \mathrm{~m}^{-2} \mathrm{~s}^{-1}$. Approximately 3 weeks prior to the experiments, the cells were cultured in L-medium with additional $\mathrm{NH}_{4}$ to avoid differences in concentrations among treatments due to $\mathrm{NH}_{4}$ excreted by the copepods [44]. Calanus finmarchicus, originally collected from the Trondheim fjord and kept in culture at Biotrix Trondheim was used as source of predator cues. Diatom cells at a concentration of $\sim 4000$ cells $\mathrm{mL}^{-1}$ were placed into two-chambered incubators; the chambers were $720 \mathrm{~mL}$ each and connected via two apertures of $7.5 \mathrm{~cm}$ in diameter. The apertures were covered with a $5-\mu \mathrm{m}$ mesh, which separated the organisms but allowed the predator cues to pass through [7]. The incubators were placed on a plankton wheel which rotated at 2 rounds $\mathrm{m}^{-1}$ for $24 \mathrm{~h}$. They were sampled for cellular toxin content, diatom cell concentration and gene expression analysis using a $100-\mathrm{mL}$ syringe. After a $24-\mathrm{h}$ acclimation period to the experimental conditions, six copepods were placed in one of the chambers to produce predator cues during the experiment. The control was without exposure to animals. Calanus finmarchicus produces copepodamides both when grazing and when starving [8]. Prior to the experiment, the copepods starved for $24 \mathrm{~h}$ so that the gut content was cleared. To ensure a constant supply of predator cues during the experiment, the animals were feeding on Pseudo-nitzschia or Fragilariopsis in the adjacent chamber, respectively.

The experiment was conducted in a temperature controlled room at $4{ }^{\circ} \mathrm{C}$ with light intensity of $\sim 100 \mu \mathrm{mol}$ photons $\mathrm{m}^{-2} \mathrm{~s}^{-1}$ and a light:dark cycle of 16:8. The experiment was initially carried out in quadruplicates, but the analyses was conducted in triplicates (for experimental workflow see Additional file 1: Figure S4). After 3 days, the experiment was terminated.

\section{Diatom concentration and toxin measurements}

After sampling for RNA extractions (below), $2 \mathrm{~mL}$ were sampled for diatom cell concentration and fixed in acidic Lugol's solution. The cells were counted in a SedgewickRafter chamber using an inverted light microscope (Olympus CKX31 at a $100 \times$ magnification), with a minimum of 400 cells.

The growth rate $(\mu)$ was determined using an exponential model:

$$
\mu=\frac{\operatorname{Ln} C_{t 2}-\operatorname{Ln} C_{t 1}}{t 2-t 1}
$$

$C$ is the cell concentrations at $t_{1}$ start and $t_{2}$ end of the experiment.

Division rate per day was calculated as:

$$
\text { Div.day }{ }^{-1}=\frac{\mu}{L N(2)}
$$

$\mu$ is the growth rate from Eq. 1.

For DA measurements $10 \mathrm{~mL}$ samples were transferred to glass tubes and centrifuged for $5 \mathrm{~min}$ at $4000 \mathrm{~g}$, supernatants were discarded and pellets transferred to $2 \mathrm{~mL}$ centrifugation tubes (Eppendorf, Hamburg, Germany) and frozen at $-20{ }^{\circ} \mathrm{C}$. DA was measured using liquid chromatography coupled with tandem mass spectrometry following [45]. In brief, samples were measured on a Sciex API 4000QTrap hybrid triple quadrupole-linear ion trap mass spectrometer (Sciex, Darmstadt, Germany) coupled to a LC 1100 liquid chromatograph (Agilent, Waldbronn, Germany). Separation was performed 
on a reverse-phase chromatography on a $\mathrm{C} 8$ phase $(50 \times 2 \mathrm{~mm}, 3 \mu \mathrm{m}$ Hypersil BDS $120 \AA$ (Phenomenex, Aschaffenburg, Germany) at $20{ }^{\circ} \mathrm{C}$. The flow rate was $0.2 \mathrm{~mL} \mathrm{~min}^{-1}$ and gradient elution was performed with two eluants, wherein eluant A was water and B was acetonitrile/water $(95: 5 \mathrm{v} / \mathrm{v})$, and both contained $2.0 \mathrm{mM}$ ammonium formate and $50 \mathrm{mM}$ formic acid. DA was detected in the positive mode by using the quantitative mass transition $m / z 312>266$ and the qualitative transition $m / z 312>161$. An external four point calibration curve $\left(10,50,100\right.$ and $\left.500 \mathrm{pg} \mu \mathrm{L}^{-1}\right)$ was used for calibration and the detection limit $(\mathrm{S} / \mathrm{N}=3)$ was determined as $0.7 \mathrm{pg} \mu \mathrm{L}^{-1}$.

\section{Harvesting and RNA extraction}

After 3 days of incubation with predator cues, the incubators were taken off the wheel. The incubators were carefully turned around minimum 10 times to ensure equal mixing of the culture prior to sampling. From each container, $60 \mathrm{~mL}$ were poured into sterile $4 \times 15 \mathrm{~mL}$ sterile centrifugation tubes (Sigma-Aldrich) and centrifuged at $4{ }^{\circ} \mathrm{C}$ and $3300 \mathrm{~g}$ for $10 \mathrm{~min}$ (Algera X-12R, Beckam Coulter, USA). Resulting cell pellets were pooled and immediately mixed with $1 \mathrm{~mL} 60^{\circ} \mathrm{C}$ hot TriReagent (Sigma-Aldrich, Steinheim, Germany) and transferred to a $2 \mathrm{~mL}$ sterile centrifugation tube containing acid washed glass beads. The cells were lysed using a tissue lyser (Power lyser 24, Qiagen, Hilden, Germany) at maximum speed for $45 \mathrm{~s}$ and immediately afterwards frozen in liquid nitrogen and stored at $-80^{\circ} \mathrm{C}$ until further use.

\section{RNA-isolation}

The cell lysate was thawed on ice and $200 \mu \mathrm{L}$ of pure chloroform was added to each vial and vortexed for $15 \mathrm{~s}$. The mixture was incubated for $5 \mathrm{~min}$ at room temperature, shaken and incubated again for $5 \mathrm{~min}$, and afterwards centrifuged for $15 \mathrm{~min}$ at $4{ }^{\circ} \mathrm{C}$ with $12,000 \mathrm{~g}$. The upper aqueous phase was transferred to a new vial, $2 \mu \mathrm{L}$ of $5 \mathrm{M}$ linear acrylamide $\left(10-20 \mu \mathrm{g} \mathrm{mL}^{-1}\right)$ and $1 / 10$ volume of $3 \mathrm{M}$ sodium-acetate $(\mathrm{pH} 5,2-5,5)$ was added, the mixture was shaken and 1:1 of $100 \%$ isopropanol was added. The mixture was then vortexed and incubated overnight (up to $14 \mathrm{~h}$ ) at $-20^{\circ} \mathrm{C}$ to precipitate RNA. The RNA-pellet was collected by 20 min centrifugation at $4{ }^{\circ} \mathrm{C}$ and $12,000 \mathrm{~g}$. The liquid was carefully removed and the pellet was washed twice, first with $1 \mathrm{~mL} 70 \%$ aqueous EtOH, centrifuged for $10 \mathrm{~min}$ at $4{ }^{\circ} \mathrm{C}$ and $12,000 g$ and afterwards with $96 \% \mathrm{EtOH}$ and centrifuged for $5 \mathrm{~min}$. After removing as much of the $\mathrm{EtOH}$ as possible, the pellet was left to air dry for 5-10 min. Finally, the pellet was dissolved in $20 \mu \mathrm{L}$ RNA/DNA RNase free water (Qiagen, Hilden, Germany). The amount of the RNA was checked on a Qubit 2.0 ${ }^{\circledR}$ fluorometer (Life Technologies).
A RNA purity check was performed using a NanoDrop ND-100 spectrometer (PeqLab, Erlangen, Germany). The integrity of the RNA was examined using the Nano Chip Assay with the 2100 Bioanalyzer device (Agilent Technologies, Böblingen, Germany). High quality RNAs, OD $260 / 280>2$ and OD260/230 >1.8, with intact ribosomal peaks (obtained from the Bioanalyzer readings) were used for building cDNA libraries.

\section{CDNA libraries}

Using the reagents provided in the TruSeq Stranded Total RNA LibraryPrep Kit High Throughput, Illumina ${ }^{\circledR}$ and following the provided manual, the polyA containing mRNA molecules were purified and fragmented. The RNA was reverse transcribed into double stranded cDNA library by fragmenting and using primers with random hexamers into first strand cDNA by reverse transcriptase. The RNA template was then removed and a replacement strand synthesized, incorporating dUTP in place of dTTP to generate double stranded (ds) cDNA. To prepare the ds cDNA for hybridization onto a flow cell, a single adenylate nucleotide was added to the $3^{\prime}$ ends of the blunt fragments to prevent them from ligating to one another during the adapter ligation reaction. A corresponding single thymine nucleotide on the $3^{\prime}$ end of the adapter provides a complementary overhang for ligating the adapter to the fragment. For ligating multiple indexing adapters to the ends of the ds cDNA RNA Adapter plated provided with the Illumina ${ }^{\circledR}$ TruSeq $^{\circledR}$ kit. After ligation, the ds cDNA was amplified with PCR. The cDNA library quality was checked on an Agilent DNA 1000 Chip Assay with the 2100 Bioanalyzer device (Agilent Technologies, Böblingen, Germany).

Each replicate was indexed prior to sequencing, so all replicates were demultiplexed and mapped separately against the reference assembly High-throughput RNA sequencing was performed on a NextSeq Illumina at the AWI.

\section{RNAseq analysis}

Using the CLC Genomics Workbench 10 (Qiagen), a de novo assembly was produced from the RNASeq reads obtained for each species. One replicate of each species failed, hence the RNAseq analysis was carried out in triplicates. The annotation of the assembled contigs was done by BLASTx search against the Clusters of Orthologous Groups of proteins, database (KOG) (downloaded 2015.02 from ftp://ftp.ncbi.nih.gov/pub/) [46] and the SwissProt database (release 2016.08) with an e-value cut-off of $<10 \mathrm{e}^{-05}$. The Kyoto Encyclopedia of Genes and Genomes (KEGG) orthology identifiers (http://www.kegg.jp/) were mapped from SwissProt identifiers at http://www.uniprot.org. The alignment 
of the RNAseq reads to the obtained contigs was done with the CLC Genomics Workbench 10 (Qiagen), with the large gap read mapping option and default settings. Differential expression analysis was done with DESeq2 in $R[47,48]$. Genes were considered to be differentially expressed when adjusted P-values were less than 0.05 and the calculated fold changes between the control and the treatment exceeded 1.5. Annotations of differentially expressed contigs according to the KOG and KEGG system were merged and manually grouped into aggregated categories.

\section{Comparative transcript analysis}

We compared our dataset with two recently published, thematically close studies [14, 25]: (1) The response to grazing copepods in a non-toxic diatom Skeletonema marioni was transcriptionally characterized [14]. (2) Four genes involved in the biosynthesis of domoic acid were identified by analyzing transcriptomic data under two growth conditions known to induce DA production in Pseudo-nitzschia multiseries [25]. The comparison of both datasets with our data was performed on the level of sequence similarities by BLAST searches. For the comparison with the Amato dataset, we used a nucleotide BLAST (BLASTn) search with a cut-off of e-25, and for the comparison with the Brunson dataset, we used a translated nucleotide query (BLASTx search) with a cut-off of e-50. Both cut-offs are conservative, but this increases the likelihood to find true orthologous genes in the comparative analysis.

\section{Additional files}

Additional file 1: Figure S1. An overview of the proposed cellular metabolic pathways for domoic acid. Figure S2. Venn diagram showing a comparison of differently expressed genes in Pseudo-nitzschia seriata inducing domoic acid (DA) production in response to grazers with data from P. multistriata producing DA during phosphate limitation and $\mathrm{pCO}_{2}$ elevation and to Skeletonema marinoi exposed to copepod grazers. Figure S3. Graphical overview of the sequence similarities of the genes commonly identified to respond to copepod grazing.

Additional file 2: Table S1. Results from the Deseq2 analyses. Annotations based on KEGG and KOG for Pseudo-nitzschia seriata. Table S2. Results from the Deseq2 analyses. Annotations based on KEGG and KOG for Fragilariopsis sp.

Additional file 3: Table S3. Differentially expressed contigs in Pseudonitzschia seriata induced with predator cues compared with P. multistriata under phosphate limiting condition in [25]. Table S4. Differentially expressed contigs in Pseudo-nitzschia seriata induced with predator cues compared with P. multistriata exposed to elevated $\mathrm{pCO}_{2}$ in [25]. Table S5. Differentially expressed contigs in Pseudo-nitzschia seriata compared with Skeletonema marinoi at time point 2 in [14] both specie are exposed to predator cues. Table S6. Differentially expressed contigs in Pseudonitzschia seriata compared with Skeletonema marinoi at time point 1 in [14] both specie are exposed to predator cues. Table S7. Results from the sequence comparison by blastx search of contigs from this study with the gene sequences from [25]. Table S8. Results from the sequence comparison by blastn search of contigs from this study with the gene sequences from [14]. Table S9. Functional and structural annotation of the 13 candidate genes we suggest are involved in response to copepod grazers.

Additional file 4. Expression profile of Pseudo-nitzschia seriata.

Additional file 5. Expression profile of Fragilariopsis sp.

\section{Abbreviations}

DA: domoic acid; GPP: geranyl pyrophosphate; MEV: mevalonate isoprenoid; MEP: methyl-erythritol phosphate-pathway.

\section{Authors' contributions}

$\mathrm{SH}$, designed the study, carried out the experiment, conducted the molecular laboratory work, analyzed the data and wrote the manuscript. SW designed the study, carried out the experiment, conducted the molecular laboratory work, analyzed the data and revised the manuscript. UJ and NL designed the study, carried out the experiment, analyzed the data, and revised the manuscript. TGN designed the study and revised the manuscript. DMH carried out the experiment and revised the manuscript. BK measured and analyzed for domoic acid and revised the manuscript. All authors read and approved the final manuscript.

\section{Author details \\ ${ }^{1}$ Natural History Museum of Denmark, University of Copenhagen, Øster Farimagsgade 5, 1353 Copenhagen K, Denmark. ${ }^{2}$ Alfred Wegener Institute, Helmholtz Centre for Polar and Marine Research, Am Handelshafen 12, 27570 Bremerhaven, Germany. ${ }^{3}$ Helmholtz Institute for Functional Marine Biodiversity, Ammerländer Heestraße 231, Oldenburg, Germany. ${ }^{4}$ National Institute of Aquatic Resources, Technical University of Denmark, Building 201, Kemitorvet, Lyngby Campus, 2800 Kgs. Lyngby, Denmark.}

\section{Acknowledgements}

We thank Dag Altin at Biotrix, for the supply of copepods. We thank Wolfgang Drebing for sample extraction and toxin measurements and Nancy Kühne for assisting with the molecular laboratory work.

\section{Competing interests}

The authors declare that they have no competing interests.

\section{Availability of data and materials}

All data generated to conclude the findings of this study are included as additional files to this article. In particular the full expression profiles for both Pseudo-nitzschia seriata and Fragilariopsis sp. can be accessed in Additional files 4 and 5 .

\section{Consent for publication \\ Not applicable.}

\section{Ethics approval and consent to participate}

Not applicable.

\section{Funding}

Funding was provided by the Independent Research Fund Denmark, Grant DFF-1323-00258 to NL. Financial support for UJ, BK, and SW was provided by the PACES research program of the Alfred-Wegener-Institute HelmholtzZentrum für Polar- und Meeresforschung. Neither of the grants provided for this study influenced the design of the study, the collection, analysis, and interpretation of data or writing the manuscript in any way.

\section{Publisher's Note}

Springer Nature remains neutral with regard to jurisdictional claims in published maps and institutional affiliations.

Received: 5 September 2018 Accepted: 14 February 2019

Published online: 26 February 2019 


\section{References}

1. Calbet A. Mesozooplankton grazing effect on primary production: a global comparative analysis in marine ecosystems. Limnol Oceanogr. 2001;46(7):1824-30

2. Pančić M, Kiørboe T. Phytoplankton defence mechanisms: traits and trade-offs. Biol Rev. 2018;93(2):1269-303

3. Amin SA, Hmelo LR, van Tol HM, Durham BP, Carlson LT, Heal KR, Morales $\mathrm{RL}$, Berthiaume CT, Parker MS, Djunaedi B, et al. Interaction and signalling between a cosmopolitan phytoplankton and associated bacteria. Nature. 2015;522(7554):98-U253.

4. Basu S, Patil S, Mapleson D, Russo MT, Vitale L, Fevola C, Maumus F, Casotti R, Mock T, Caccamo M. Finding a partner in the ocean: molecular and evolutionary bases of the response to sexual cues in a planktonic diatom. New Phytol. 2017;215(1):140-56.

5. Bergkvist J, Thor P, Jakobsen HH, Wangberg SA, Selander E. Grazerinduced chain length plasticity reduces grazing risk in a marine diatom. Limnol Oceanogr. 2012;57(1):318-24.

6. Harðardóttir S, Pančić M, Tammilehto A, Krock B, Møller EF, Nielsen TG, Lundholm N. Dangerous relations in the arctic marine food web: interactions between toxin producing Pseudo-nitzschia diatoms and Calanus copepodites. Mar Drugs. 2015;13(6):3809-35.

7. Tammilehto A, Nielsen TG, Krock B, Møller EF, Lundholm N. Induction of domoic acid production in the toxic diatom Pseudo-nitzschia seriata by calanoid copepods. Aquat Toxicol. 2015;159:52-61.

8. Lundholm N, Krock B, John U, Skov J, Cheng J, Pančić M, Wohlrab S, Rigby $K$, Nielsen TG, Selander E, et al. Induction of domoic acid production in diatoms - types of grazers and diatoms are important. Harmful Algae. 2018;79:64-73.

9. Selander E, Kubanek J, Hamberg M, Andersson MX, Cervin G, Pavia H. Predator lipids induce paralytic shellfish toxins in bloom-forming algae. Proc Natl Acad Sci. 2015;112(20):6395-400

10. Grebner W, Berglund EC, Berggren F, Eklund J, Harðadóttir S, Andersson MX, Selander E. Induction of defensive traits in marine planktonnew copepodamide structures. Limnol Oceanogr. 2018. https://doi. org/10.1002/Ino.11077.

11. Selander E, Berglund EC, Engström P, Berggren F, Eklund J, Harðardóttir S, Lundholm N, Grebner W, Andersson MX. Copepods drive large-scale trait mediated effects in marine plankton. In: Science Advanced; 2019.

12. Wohlrab S, Tillmann U, Cembella A, John U. Trait changes induced by species interactions in two phenotypically distinct strains of a marine dinoflagellate. ISME J. 2016;10(11):2658.

13. Wohlrab S, Iversen MH, John U. A molecular and co-evolutionary context for grazer induced toxin production in Alexandrium tamarense. PLOS ONE. 2010;5(11):e15039.

14. Amato A, Sabatino V, Nylund GM, Bergkvist J, Basu S, Andersson MX, Sanges R, Godhe A, Kiorboe T, Selander E, et al. Grazer-induced transcriptomic and metabolomic response of the chain-forming diatom Skeletonema marinoi. ISME J. 2018;12(6):1594-604.

15. Lundholm N. Taxonomic reference list of harmful micro algae. http:// www.marinespecies.org/hab. Accessed 17 Jan 2019.

16. Lelong A, Hégaret $H$, Soudant P, Bates SS. Pseudo-nitzschia (Bacillariophyceae) species, domoic acid and amnesic shellfish poisoning: revisiting previous paradigms. Phycologia. 2012:51(2):168-216.

17. Bates SS, Hubbard KA, Lundholm N, Montresor M, Leaw CP. Pseudonitzschia, Nitzschia, and domoic acid: new research since 2011. Harmful Algae. 2018;79:3-43.

18. Douglas DJ, Ramsey UP, Walter JA, Wright JLC. Biosynthesis of the neurotoxin domoic acid by the marine diatom Nitzschia-pungens forma multiseries, determined with c-13-labeled precursors and nuclear-magnetic-resonance. J Chem Soc Chem Commun. 1992;9:714-6.

19. Ramsey UP, Douglas DJ, Walter JA, Wright JL. Biosynthesis of domoic acid by the diatom Pseudo-nitzschia multiseries. Nat Toxins. 1998;6(3-4):137-46

20. Pan Y, Bates SS, Cembella AD. Environmental stress and domoic acid production by Pseudo-nitzschia: a physiological perspective. Nat Toxins. 1998:6(3-4):127-35.

21. Lohr M, Schwender J, Polle JE. Isoprenoid biosynthesis in eukaryotic phototrophs: a spotlight on algae. Plant Sci. 2012;185:9-22.

22. Di Dato V, Musacchia F, Petrosino G, Patil S, Montresor M, Sanges R, Ferrante MI. Transcriptome sequencing of three Pseudo-nitzschia species reveals comparable gene sets and the presence of nitric oxide synthase genes in diatoms. Sci Rep. 2015;5:12329.

23. Savage TJ, Smith GJ, Clark AT, Saucedo PN. Condensation of the isoprenoid and amino precursors in the biosynthesis of domoic acid. Toxicon. 2012:59(1):25-33.

24. Maeno Y, Kotaki Y, Terada R, Cho Y, Konoki K, Yotsu-Yamashita M. Six domoic acid related compounds from the red alga, Chondria armata, and domoic acid biosynthesis by the diatom, Pseudo-nitzschia multiseries. Sci Rep. 2018;8(1):356.

25. Brunson JK, McKinnie SMK, Chekan JR, McCrow JP, Miles ZD, Bertrand EM, Bielinski VA, Luhavaya H, Obornik M, Smith GJ, et al. Biosynthesis of the neurotoxin domoic acid in a bloom-forming diatom. Science. 2018;361(6409):1356

26. Sun J, Hutchins DA, Feng Y, Seubert EL, Caron DA, Fu F-X. Effects of changing pCO2 and phosphate availability on domoic acid production and physiology of the marine harmful bloom diatom Pseudo-nitzschia multiseries. Limnol Oceanogr. 2011;56(3):829-40.

27. Smith GJ, Ladizinsky N, Miller PE. Amino acid profiles in species and strains of Pseudo-nitzschia from Monterey Bay California: insights into the metabolic role(s) of domoic acid. Harmful Algal Blooms. 2000;2001:320-3.

28. Boissonneault KR, Henningsen BM, Bates SS, Robertson DL, Milton S, Pelletier J, Hogan DA, Housman DE. Gene expression studies for the analysis of domoic acid production in the marine diatom Pseudo-nitzschia multiseries. BMC Mol Biol. 2013;14:25.

29. Lundholm N, Hasle GR. Are Fragilariopsis cylindrus and Fragilariopsis nana bipolar diatoms? - morphological and molecular analyses of two sympatric species. Nova Hedwig Beih. 2008;133:231-50.

30. Kropuenske LR, Mills MM, van Dijken GL, Bailey S, Robinson DH, Welschmeyer NA, Arrigoa KR. Photophysiology in two major Southern Ocean phytoplankton taxa: photoprotection in Phaeocystis antarctica and Fragilariopsis cylindrus. Limnol Oceanogr. 2009;54(4):1176-96.

31. Hamm CE, Merkel R, Springer O, Jurkojc P, Maier C, Prechtel K, Smetacek $V$. Architecture and material properties of diatom shells provide effective mechanical protection. Nature. 2003;421(6925):841-3.

32. Harðardóttir S, Hjort DM, Wohlrab S, Krock B, John U, Nielsen TG, Lundholm N. Trophic interactions, toxicokinetics, and detoxification processes in a domoic acid-producing diatom and two copepod species. Limnol Oceanogr. 2018. https://doi.org/10.1002//no.11078.

33. Harðardóttir S, Krock B, Wohlrab S, John U, Nielsen TG, Lundholm N. Can domoic acid affect escape response in copepods? Harmful algae. 2018;79:50-2

34. DeWitt TJ. Costs and limits of phenotypic plasticity: tests with predatorinduced morphology and life history in a freshwater snail. J Evol Biol. 1998;11(4):465-80.

35. Van Kleunen M, Fischer M. Progress in the detection of costs of phenotypic plasticity in plants. New Phytol. 2007;176(4):727-30.

36. Van Donk E, lanora A, Vos M. Induced defences in marine and freshwater phytoplankton: a review. Hydrobiologia. 2011;668(1):3-19.

37. Bell G, Collins S. Adaptation, extinction and global change. Evol Appl. 2008;1(1):3-16

38. Eisenreich W, Bacher A, Arigoni D, Rohdich F. Biosynthesis of isoprenoids via the non-mevalonate pathway. Cell Mol Life Sci. 2004;61(12):1401-26.

39. Lichtenthaler HK (2010) Chapter 7 The Non-mevalonate DOXP/MEP (Deoxyxylulose 5-Phosphate/Methylerythritol 4-Phosphate) Pathway of Chloroplast Isoprenoid and Pigment Biosynthesis. In: Rebeiz CA, Benning C, Bohnert HJ, Daniell H, Hoober JK, Lichtenthaler HK, Portis AR, Tripathy BC (eds) The Chloroplast. Advances in Photosynthesis and Respiration, vol 31. Springer, Dordrecht, pp 95-118.

40. Rai V. Role of amino acids in plant responses to stresses. Biol Plant. 2002:45(4):481-7

41. Krell A, Funck D, Plettner I, John U, Dieckmann G. Regulation of proline metabolism under salt stress in the psychrophilic diatom Fragilariopsis cylindrus (bacillariophyceae). J Phycol. 2007;43(4):753-62.

42. Rokitta SD, von Dassow P, Rost B, John U. P-and N-depletion trigger similar cellular responses to promote senescence in eukaryotic phytoplankton. Front Mar Sci. 2016:3:109.

43. Guillard RRL, Hargraves PE. Stichochrysis-immobilis is a diatom, not a chyrsophyte. Phycologia. 1993;32(3):234-6.

44. Corner E, Newell B. On the nutrition and metabolism of zooplankton IV. The forms of nitrogen excreted by Calanus. J Mar Biol Assoc UK. 1967:47(1):113-20. 
45. Tammilehto A, Nielsen TG, Krock B, Møller EF, Lundholm N. Calanus spp.vectors for the biotoxin, domoic acid, in the Arctic marine ecosystem? Harmful Algae. 2012;20:165-74.

46. Tatusov RL, Fedorova ND, Jackson JD, Jacobs AR, Kiryutin B, Koonin EV, Krylov DM, Mazumder R, Mekhedov SL, Nikolskaya AN. The COG database: an updated version includes eukaryotes. BMC Bioinform. 2003;4(1):41.
47. Love MI, Huber W, Anders S. Moderated estimation of fold change and dispersion for RNA-seq data with DESeq2. Genome Biol. 2014;15(12):550.

48. Team RC. R: a language and environment for statistical computing. $R$ Foundation for Statistical Computing: Vienna; 2013. p. 2014.

Ready to submit your research? Choose BMC and benefit from:

- fast, convenient online submission

- thorough peer review by experienced researchers in your field

- rapid publication on acceptance

- support for research data, including large and complex data types

- gold Open Access which fosters wider collaboration and increased citations

- maximum visibility for your research: over 100M website views per year

At BMC, research is always in progress.

Learn more biomedcentral.com/submissions 